\title{
Scrotal reconstruction with superomedial fasciocutaneous thigh flap
}

\section{Reconstrução escrotal com retalho fasciocutâneo superomedial da coxa}

\author{
Daniel Francisco Mello, TCBC-SP1; Americo Helene Júnior ${ }^{1}$
}

\begin{abstract}
A B S T R A C T
Objective: to describe the use of a superomedial fasciocutaneous thigh flap for scrotal reconstruction in open areas secondary to the surgical treatment of perineal necrotizing fasciitis (Fournier's gangrene). Methods: retrospective analysis of cases treated at the Plastic Surgery Service of Santa Casa de Misericórdia, São Paulo, from 2009 to 2015. Results: fifteen patients underwent scrotal reconstruction using the proposed flap. The mean age was 48.9 years (28 to 66). Skin loss estimates in the scrotal region ranged from 60 to $100 \%$. Definitive reconstruction was performed on average 30.6 days (22 to 44) after the initial surgical treatment. The mean surgical time was 76 minutes (65 to 90) to obtain the flaps, bilateral in all cases. Flap size ranged from $10 \mathrm{~cm}$ to $13 \mathrm{~cm}$ in the longitudinal direction and $8 \mathrm{~cm}$ to $10 \mathrm{~cm}$ in the cross-sectional direction. The complication rate was $26.6 \%$ (four cases), related to the occurrence of segmental and partial dehiscence. Conclusion: the superomedial fasciocutaneous flap of thigh is a reliable and versatile option for the reconstruction of open areas in the scrotal region, showing adequate esthetic and functional results.
\end{abstract}

Keywords: Scrotum. Skin. Wounds and Injuries. Wound Closure Techniques. Fournier Gangrene.

\section{INTRODUCTION}

P erineal necrotizing fasciitis, also called Fournier's gangrene, was first described in 1883. It has high rates of morbidity and mortality. Treatment is predominantly surgical, including extensive and early drainage and debridement, associated with volume replacement and broad-spectrum intravenous antibiotic therapy.

The process etiology is identified in approximately $70 \%$ to $90 \%$ of cases, and may be related to dermatological, urological and colorectal diseases or surgical procedures - including surgical complications of hemorrhoidectomy, orchiectomy, herniorrhaphy, vasectomy and postectomy ${ }^{1,2}$. The association with diabetes mellitus (DM) is frequent, with rates ranging from 20 to $60 \%$ in the literature ${ }^{3}$. Eke ${ }^{1}$, in a systematic review including 1726 cases from 1950 to 1999, reports etiology identification in more than $90 \%$ of the cases, with dermatological infections being the most frequent ones (24\%), followed by anorectal (21\%) and urological (19\%) cases.

The male gender is more frequently affected, and skin loss in the scrotal and perineal region is very common. The participation of the plastic surgeon is necessary to carry out the reconstruction, after clinical stabilization of the patient. The scrotal reconstruction should maintain the physiological and esthetic characteristics, as much as possible. The ideal procedure includes performing a one-time reconstruction with adequate skin and subcutaneous thickness, resistant to traction and movements, with minimal sequelae to the donor area, which can maintain the thermoregulation of the testicles and shows the natural ptosis of the scrotal region..$^{4,5}$

The choice of technique depends on factors related to the defect itself, such as size and location, as well as preferences of the surgical team and the patient. Multiple techniques have been described, and there

1 - Irmandade da Santa Casa de Misericórdia de São Paulo, Discipline of Plastic Surgery, São Paulo, SP, Brazil. 
is not a single one that can be considered ideal or even applicable to all cases $^{4,5}$.

This study aims to describe the use of the superomedial fasciocutaneous thigh flap (SMFCTF) for scrotal reconstruction in open areas secondary to the surgical treatment of perineal necrotizing fasciitis.

\section{METHODS}

Retrospective analysis of medical and photographic records of patients submitted to surgical treatment of Fournier's gangrene and scrotal reconstruction with SMFCTF, in the period between 2009 and 2015, at Central Hospital of Irmandade da Santa Casa de Misericórdia de São Paulo.

Mean age, presence of comorbidities, etiology, associated penile involvement and use of ostomies were analyzed. Estimates of scrotal skin loss were calculated as relative percentages. The number of debridement procedures and time to start the reconstruction were evaluated. Regarding the flap itself, the dimensions and complications found were evaluated. The number of total surgical procedures related to the reconstruction and length of hospital stay were also analyzed.

To perform the SMFCTF, the patient was positioned in the lithotomy position, with abduction and partial flexion of the lower limbs under spinal block. Resection of fibrotic-scar tissue and excessive granulation was performed in the entire affected region - perineum, testes and funiculi (Figures 1 and 2). The open area was measured to facilitate flap demarcation. A transposition flap $\left(90^{\circ}\right)$ of the superomedial region of the thigh was used, with dissection in the fasciocutaneous plane and evidencing the gracilis muscle throughout the bed, without direct handling. The suture was made by flap planes in the midline and base of the penis, as well as in the thigh and perineum. The donor area was submitted to primary closure, by planes, in all cases. There was no need to use aspiration drainage (Figures 3 to 6).

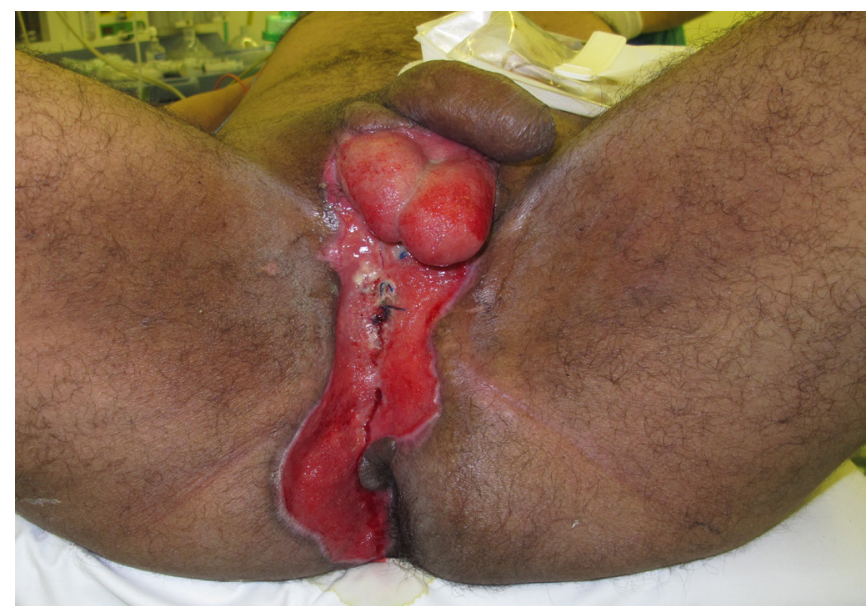

Figure 1. Postoperative period: 28 days of debridement.

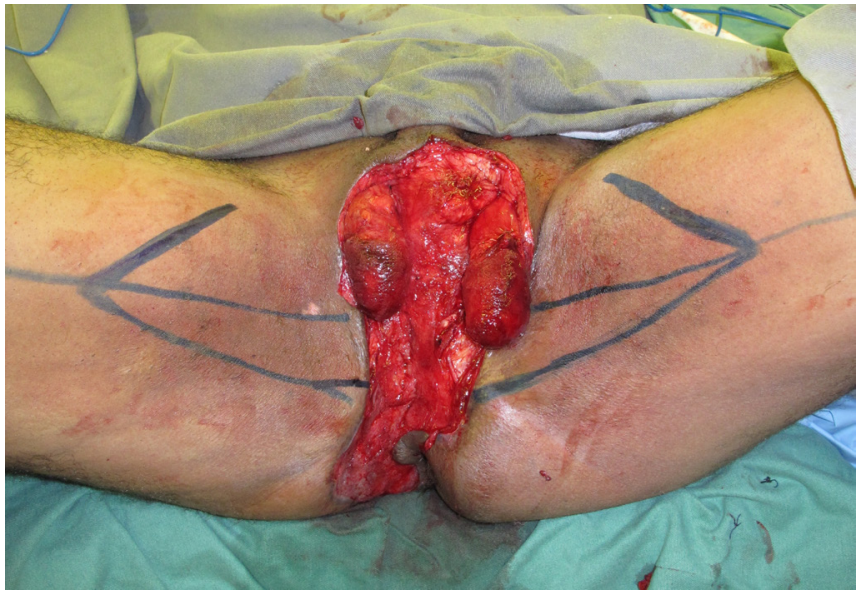

Figure 2. Bilateral demarcation of the flaps.

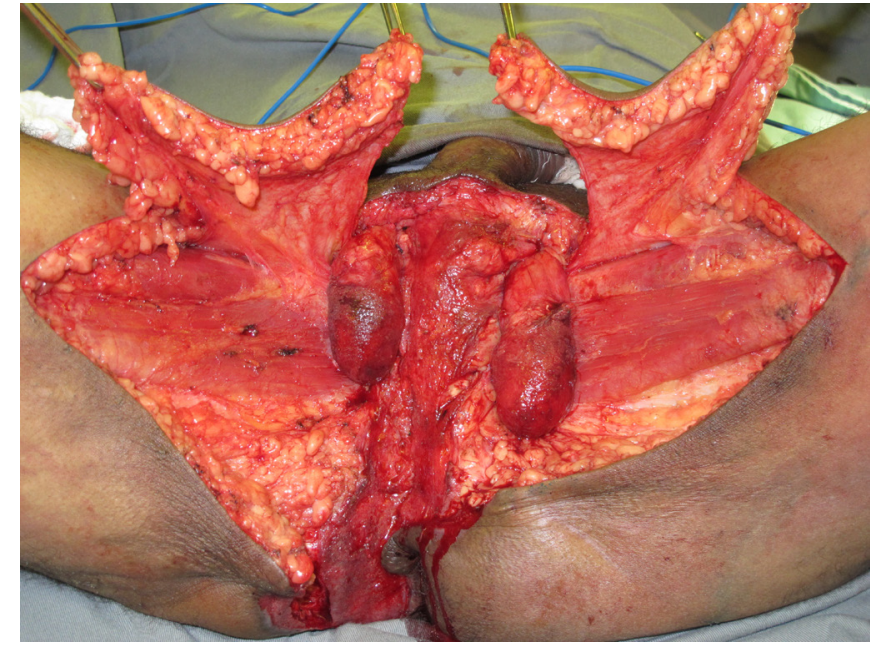

Figure 3. Dissected and mobilized flaps. 


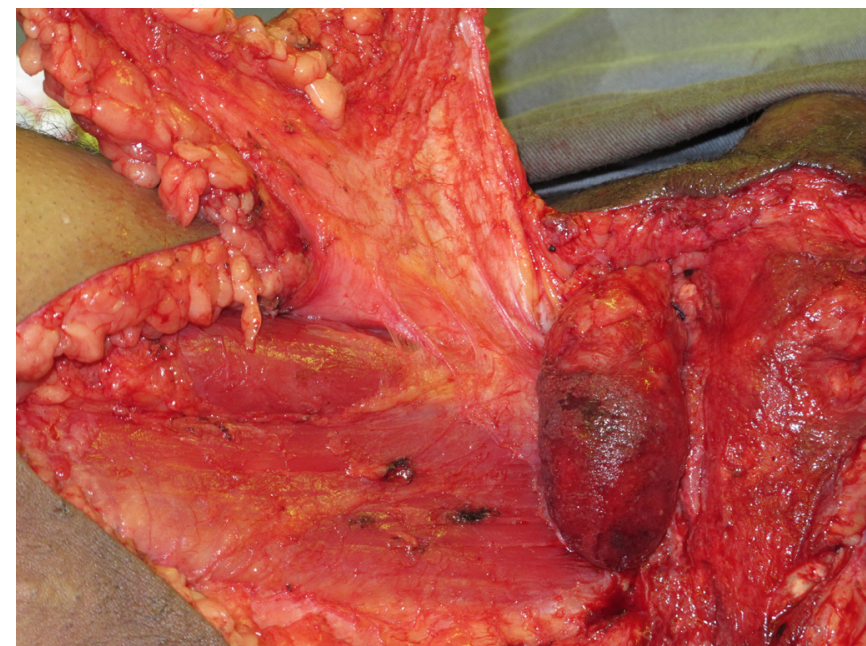

Figure 4. Detailed view of the vascular pedicle.

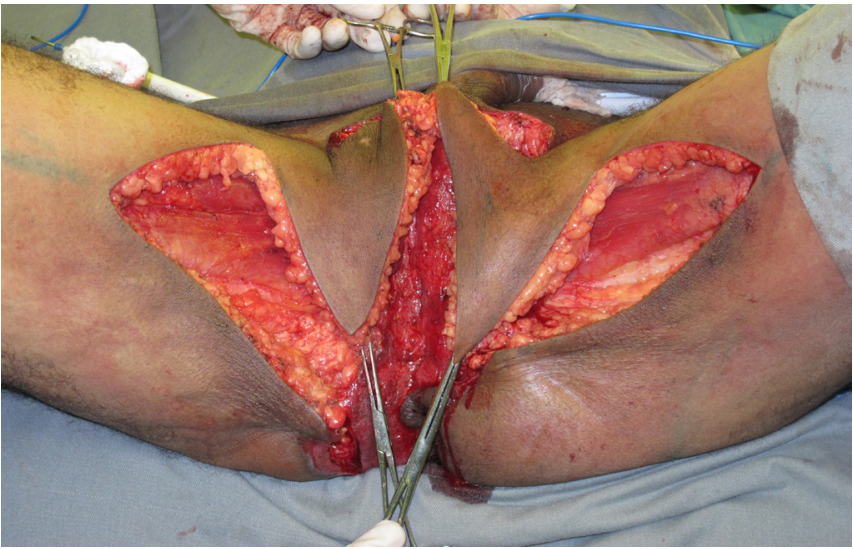

Figure 5. Medially transposed flaps.

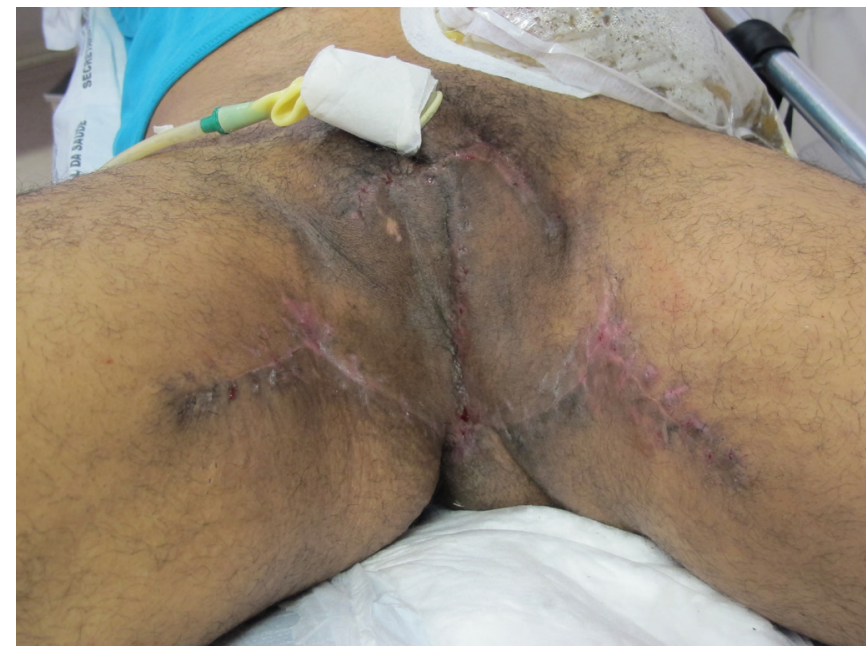

Figure 6. Thirty days postoperatively.

\section{RESULTS}

Fifteen patients with a mean age of 48.9 years (28 to 66) were assessed. Comorbidities were identified in ten patients $(66.7 \%)$, with DM being the most frequent one. The process etiology was identified in ten cases $(66.7 \%)$, being mainly skin infections and anorectal abscesses. Penile skin involvement was observed in six patients (40\%). Ostomies were performed in five cases, mainly in those who had initial treatment in another service and who were transferred to our institution for reconstruction.

Estimates of skin loss at the scrotal region ranged from 60 to $100 \%$. In the initial stage of the surgical treatment, a mean of 1.33 debridement procedures was performed per patient, being one procedure performed in ten patients and two in five. Definitive reconstruction was performed on average 30.6 days ( 22 to 44 ) after the initial treatment. The mean surgical time for reconstruction with the SMFCTF was 76 minutes (65 to 90). The flaps were bilateral in all cases. Flap size ranged from $10 \mathrm{~cm}$ to $13 \mathrm{~cm}$ in the longitudinal direction and from $8 \mathrm{~cm}$ to $10 \mathrm{~cm}$ in the cross-sectional direction.

The number of reconstruction procedures was 1.4 surgeries/patient. One procedure was performed in nine patients, two in four patients and three in two patients. Sequential treatment was an option in cases with abdominal or perineal region involvement, with sutures or skin grafting being performed. We also chose to perform skin grafting on the penile body in an isolated surgical procedure, when necessary.

Complications were observed in four cases (26.6\%), associated with three occurrences of segmental dehiscence (less than $2 \mathrm{~cm}$ ) and one area of epitheliolysis, also localized. These situations were treated in a conservative and non-surgical manner. The total hospital length of stay was on average 39.1 days (26 to 54 ).

\section{DISCUSSION}

Scrotal skin loss may be secondary to trauma, oncological surgeries and infections ${ }^{6}$. An important technical aspect for the reconstruction is the granulation tissue resection that is incarcerating the funiculus, testis and perineal region?. In this way, the actual defect is evaluated to program the suitable size(s) of the flap(s).

Ostomies should be avoided whenever possible, and are usually indicated in cases of anorectal lesions (perforations or fistulas), as well as sphincter lesions ${ }^{8}$. 
Candelária et al..$^{3}$ did not demonstrate an advantage of this procedure in survival rates. The use of rectal catheters may help in the acute phase of treatment, but should not be used for prolonged periods ${ }^{\text {. }}$.

Negative pressure therapy is an option in the wound preparation phase after complete debridement of the devitalized tissues ${ }^{6,9}$. We emphasize the need for additional care for the adaptation of the adhesive films to the perineal contours and the adequate isolation of the perianal region, which is also an indication for rectal catheters in the patients that were not submitted to an ostomy.

The following are technical options described for scrotal reconstruction: (1) secondary wound healing, (2) primary synthesis, (3) skin grafting, (4) residual scrotal myocutaneous flap, (5) local and locoregional cutaneous flaps, (6) locoregional and distant fasciocutaneous flaps, and (7) locoregional and distant myocutaneous flaps. In general, the literature reports $50 \%$ of scrotal skin loss as the limit for the indication of simpler reconstruction techniques. In these smaller losses, myocutaneous advancement flaps of the residual scrotum or primary suture are usually recommended. For losses $>50 \%$, the indication should be for skin grafting or locoregional or even distant flaps ${ }^{2,4-6}$. Franco et al. ${ }^{7}$ describe the use of locoregional flaps for losses $>$ 2/3.

The transposition of the testes to the subcutaneous tissue of the upper thigh region is an option for temporary protection. Alterations in spermatogenesis, secondary to increased local temperature, have been described, as well as cases of testicular atrophy and chronic pain. The secondary psychological alterations should also be considered ${ }^{10-13}$. We did not have any cases treated with this technique, which, in our opinion, should not be used. Tissue expansion performed at two different moments is described by Khan et al. ${ }^{6}$ as an option. They also mention the performance of rapid intraoperative expansion.

Partial skin grafting is advocated by several authors, such as Tan et al. ${ }^{8}$ and Maguina et $a l^{13}$, with the suture being normally performed between the testes, initially. Special care is needed to fix the grafts for proper integration. The tunica vaginalis should be present and with favorable granulation tissue.

Mopuri et al. ${ }^{4}$ describe the use of transposition fasciocutaneous flaps, with a posteroinferior basis. Hsu et al. ${ }^{11}$ describe the use of the gracilis myofasciocutaneous flap in V-Y advancement of the entire medial aspect of the thigh. Muscle flaps are described associated with partial skin grafting. The gracilis and rectus abdominis flaps (VRAM) were used by Ellabban and Towsend ${ }^{10}$. Balbinot et al. ${ }^{2}$ highlight the functional aspect of the sequel after the removal of each of these muscles, with the gracilis being associated with potential alterations in lower-limb abduction. The resulting volume of the added musculature is a significant limitation.

Fasciocutaneous flaps of the posterior thigh region, with a pedicle based on the inferior gluteal artery may be an option. However, it is necessary to modify the patient's position during the intraoperative period (initial ventral decubitus, changing to the lithotomy position), with the flap thickness also being a limiting factor. Chen et al. ${ }^{9}$ describe the use of island flaps, based on perforators of the medial thigh region, in addition to cases using the anterolateral pedicle flap of the thigh (ALT). Yu et al. ${ }^{14}$ also describe the use of ALT.

The use of SMFCTF was initially described by Hirshowitz et al. ${ }^{15}$ as a "probably" arterial flap using a different demarcation, following the medial thigh curvature. The vascular supply from branches of the external pudendal artery, anterior branch of the obturator artery and branches of the medial femoral circumflex artery were described.

Our choice to use bilateral flaps is based on some aspects: smaller flaps can be used, with easier and simpler closure of the donor areas, as well as the creation of a median raphe. These aspects are also highlighted by Maguina et al. ${ }^{12}$. The demarcation we used, with a triangular and predominantly longitudinal donor area, is similar to that used by Balbinot ${ }^{2}$, Ferreira ${ }^{5}$ and Maguina ${ }^{12}$.

Regarding the advantages of the SMFCTF, one can consider that, normally, the donor area is not affected, the thickness of the skin and subcutaneous tissue can be considered adequate, the reconstruction can be performed in a single stage for the scrotal defects without changing the patient's position on the surgical table. Mauro ${ }^{16}$ points out that this flap is technically simple, rarely shows ischemia, and provides excellent esthetic results. As a disadvantage, one can consider the limitation of the cross-sectional diameter and the skin elasticity of the medial thigh region. Maguina et $a . .^{12}$ also consider the 
potential technical difficulty due to the thickness of the subcutaneous tissue in obese patients.

We can conclude that SMFCTF is a reliable and versatile option for the reconstruction of open areas in the scrotal region, showing adequate functional and esthetic results. It has been observed that the use of this flap is not technically difficult or time-consuming, and does not result in significant sequelae to the donor area.

\title{
RE S U M O
}

\begin{abstract}
Objetivo: descrever a utilização do retalho fasciocutâneo superomedial da coxa para a reconstrução escrotal em áreas cruentas secundárias ao tratamento cirúrgico da fasceíte necrosante do períneo (gangrena de Fournier). Métodos: análise retrospectiva de casos atendidos no Serviço de Cirurgia Plástica da Irmandade da Santa Casa de Misericórdia de São Paulo, no período de 2009 a 2015. Resultados: quinze pacientes foram submetidos à reconstrução escrotal utilizando o retalho proposto. A média de idade foi de 48,9 anos (28 a 66). A estimativa de perda cutânea da região escrotal variou de 60 a 100 \%. A reconstrução definitiva foi realizada em média 30,6 dias (22 a 44) após o tratamento cirúrgico inicial. O tempo cirúrgico médio foi de 76 minutos (65 a 90) para a realização dos retalhos, bilaterais em todos os casos. O tamanho dos retalhos variou de $10 \mathrm{~cm}$ a $13 \mathrm{~cm}$ no sentido longitudinal por $8 \mathrm{~cm}$ a $10 \mathrm{~cm}$ no sentido transverso. O índice de complicações observado foi de $26,6 \%$ (quatro casos), referentes à ocorrência de deiscências segmentares e parciais. Conclusão: o retalho fasciocutâneo superomedial da coxa é uma opção confiável e versátil para a reconstrução de áreas cruentas na região escrotal, apresentando resultados estéticos e funcionais adequados.
\end{abstract}

Descritores: Escroto. Pele. Ferimentos e Lesões. Técnicas de Fechamento de Ferimentos. Gangrena de Fournier

\section{REFERENCES}

1. Eke N. Fournier's gangrene: a review of 1726 cases. $\mathrm{Br}$ J Surg. 2000;87(6):718-28.

2. Balbinot $P$, Ascenço ASK, Nasser IJG, Berri DT, Maluf Jr I, Lopes MC, et al. Síndrome de Fournier: reconstrução de bolsa testicular com retalho fasciocutâneo de região interna de coxa. Rev Bras Cir Plást. 2015;30(2):32934.

3. Candelária PAP, Klug WA, Capelhuchnik P, Fang CB. Síndrome de Fournier: análise dos fatores de mortalidade. Rev Bras Coloproct. 2009;29(2):197202.

4. Mopuri N, O'Connor EF, Iwuagwu FC. Scrotal reconstruction with modified pudendal thigh flaps. J Plast Reconstr Aesthet Surg. 2016;69(2):278-83.

5. Ferreira PC, Reis JC, Amarante JM, Silva AC, Pinho CJ, Oliveira IC, et al. Fournier's Gangrene: a review of 43 reconstructive cases. Plast Reconst Surg. 2007;119(1):175-84.

6. Khan Q, Knight RJW, Goodwin-Walters A. Scrotal reconstruction: a review and a proposed algorithm. Eur J Plast Surg. 2013;36(7):399-406.

7. Franco D, Rodrigues C, Tavares Filho JM, Imoto F, Franco T. Reconstrução do escroto após fascite necrosante. Rev Bras Cir Plast. 2010;25(2):349-54.

8. Tan BK, Rasheed MZ, Wu WT. Scrotal reconstruction by testicular apposition and wrap-around skin grafting. J Plast Reconst Aesthet Surg. 2011;64(7):944-8.

9. Chen SY, Fu JP, Chen TM, Chen SG. Reconstruction of scrotal and perineal defects in Fournier's gangrene. J Plast Reconst Aesthet Surg. 2011;64(4):528-34.

10. Ellabban MG, Towsend PL. Single-stage muscle flap reconstruction of major scrotal defects: report of two cases. Br J Plast Surg. 2003;56(5):489-93.

11. Hsu $H$, Lin CM, Sun TB, Cheng LF, Chien SH. Unilateral gracilis myofasciocutaneous advancement flap for single stage reconstruction of scrotal and perineal defects. J Plast Reconst Aesthet Surg. 2007;60(9):1055-9.

12. Maguina P, Paulius KL, Kale S, Kalimuthu R. Medial thigh fasciocutaneous flaps for reconstruction of the scrotum following Fournier gangrene. Plast Reconst Surg. 2010;125(1):28e-30e.

13. Maguina $P$, Palmieri TL, Greenhalgh DG. Split thickness skin grafting for recreation of the scrotum following Fournier's gangrene. Burns. 2003;29(8):857-62.

14. Yu P, Sanger JR, Matloub HS, Gosain A, Larson D. Anterolateral thigh fasciocutaneous island flaps in 
perineoscrotal reconstruction. Plast Reconstr Surg. 2002;109(2):610-6.

15. Hirshowitz B, Moscona R, Kaufman T, Pnini A. One-stage reconstruction of the scrotum following Fournier's syndrome using a probable arterial flap. Plast Reconst Surg. 1980;66(4):608-12.

16. Mauro $V$. Retalho fáscio-cutâneo da região interna de coxa para reconstrução escrotal na síndrome de Fournier - relato de caso. Rev Bras Cir Plast. 2011;26(4):707-09.
Received in: 01/09/2017

Accepted for publication: 23/11/2017

Conflict of interest: none.

Source of funding: none.

\section{Mailing address:}

Daniel Francisco Mello

E-mail: mello.plastica@gmail.com /

clinica.bms@hotmail.com

(cc) BY 